\title{
The Role of ACTH in the Pathogenesis of Polycystic Ovarian Syndrome in Rats: Hormonal Profiles and Ovarian Morphology
}

\author{
C. BARAVALLE ${ }^{1,2}$, N. R. SALVETTI ${ }^{1,2}$, G. A. MIRA ${ }^{2}$, J. A. LORENTE ${ }^{1}$, \\ H. H. ORTEGA,
}

${ }^{1}$ Department of Anatomy and Histology and ${ }^{2}$ Center for Experimental Biology and Laboratory of Animal Sciences, Faculty of Veterinary Sciences, National University of Litoral, Esperanza, Santa Fe, Argentina

Received October 4, 2005

Accepted February 3, 2006

On-line available February 23, 2006

\begin{abstract}
Summary
Numerous hypotheses have been proposed about the pathogenesis of the polycystic ovarian syndrome (PCOS). However, hormonal control of persistent follicles has not been established. The objective of the present study was to compare the follicular structure and hormonal profiles of rats treated with the adrenocorticotrophic hormone (ACTH) with two experimental models of PCOS. ACTH-treated animals were compared with those exposed to continuous light, those treated with estradiol valerate, and with control (in proestrous and diestrous). Serum hormone levels, histomorphometrical changes, and immunoexpression of vimentin, cytokeratins, cadherins, and proliferating cell nuclear antigen (PCNA) were examined. Treatment with ACTH resulted in an elevation of corticosterone secretion with LH reduction but without changes in ovarian morphology. Although stress (or ACTH) stimulation may be only one of pathophysiological mechanisms involved in follicular cyst pathogenesis in other species, we do not have important evidence to suppose that this would happen in rats.
\end{abstract}

Key words

ACTH $\bullet$ Ovary $\bullet$ Polycystic Ovarian Syndrome $\bullet$ Rat $\bullet$ Stress

\section{Introduction}

Polycystic ovarian syndrome (PCOS) is the most common and least understood endocrine disorder affecting approximately $5 \%$ of women of reproductive age. It is considered a syndrome not a disease, although the term "polycystic ovarian disease" is often used synonymously, but incorrectly, to describe this syndrome, which is manifested by heterogeneous clinical symptoms (Xita et al. 2002).

Numerous experimental models to assess PCOS in rats have been developed. The following hormonal substances, among others, have been employed to induce this condition: estradiol valerate, dehydroepiandrosterone, neonatal androgenization, and continuous light exposure (Mahesh et al. 1987, Mahajan 1988, 
Salvetti et al. 2003, 2004a,b).

On the other hand, stress has been implicated in the etiology of spontaneously occurring persistent follicles in cattle and sheep. In cattle, the preovulatory luteinizing hormone (LH) surge is sensitive to the inhibitory effects of exogenous adrenocorticotrophic hormone (ACTH), and such inhibition results in the development of persistent follicles (Phogat et al. 1997, Dobson et al. 2000). However, the reproductive hormonal control of the consequent development of either the persistent follicle or subsequent follicles was not examined in these studies.

The objective of the present study was to compare the follicular structure and hormonal profiles of rats treated with ACTH with two experimental models of PCOS.

\section{Methods}

\section{Animals and treatment}

Female Wistar rats (175-200 g) were provided by the Center for Experimental Biology and Laboratory Animal Sciences, Faculty of Veterinary Sciences, UNL. Before the experiment, the animals were kept under controlled cycle of light and darkness (lights on from 06:00 to $20: 00 \mathrm{~h}$ ), and a temperature range of $20-24{ }^{\circ} \mathrm{C}$ with free access to water and commercial food (Cargill, Argentina). Lighting was provided by banks of General Electric 4 coolwhite $40-\mathrm{W}$ fluorescent tubes to obtain a light intensity of 350 lux at $1 \mathrm{~m}$ above the floor (Salvetti et al. 2004a). All procedures were carried out according to the Guide for the Care and Use of Laboratory Animals (National Research Council 1996).

Forty animals displaying at least two normal 4-5 days of estrous cycles, just before treatment, were allocated to four groups: The control group received an equivalent volume of vehicle and the animals were sacrificed after 10 weeks, in proestrous (C-P) $(n=5)$ to obtain serum and preovulatory tertiary follicles, and in diestrous (C-D) $(n=5)$ to obtain serum and growing follicles. The animals in the continuous light group (L) were placed in the conditions described, except that the light was extended to $24 \mathrm{~h}$ and the rats were sacrificed after 105 days (Salvetti et al. 2004a). The estradiol valerate (EV)-treated group was injected with a single 2-mg IM dose of EV and the rats were sacrificed at 60 days (Progynon Depot, Schering, Buenos Aires, Argentina) (Schulster et al. 1984, Farookhi et al. 1985). The animals belonging to the ACTH-treated group received an equivalent to $20 \mathrm{UI} / \mathrm{kg}(200 \mu \mathrm{g} / \mathrm{kg})$ of ACTH (ACTHElea, Elea, Buenos Aires, Argentina) subcutaneously every $24 \mathrm{~h}$ for 18 days and were sacrificed $24 \mathrm{~h}$ after the last injection (Fraser et al. 2001, Kitamura et al. 2002).

\section{Vaginal smears}

Smears obtained by vaginal washing were examined under a microscope for the relative abundance of nucleated epithelial cells, cornified cells, and leukocytes. Cycles with duration of 4-5 days were considered regular. The observation of cornified cells in the smears during a minimum of 10 serial days was defined as persistent vaginal cornification (PVC) and considered to be an indication of follicular cystic development (Salvetti et al. 2004a).

\section{Tissue sampling}

All the animals were killed by decapitation, at around 9:00 h, trunk blood was collected, and the serum stored at $-20^{\circ} \mathrm{C}$ until used for hormone assays. The ovaries were dissected and fixed in $10 \%$ buffered formalin for $6 \mathrm{~h}$ at room temperature and washed in a phosphate buffer saline (PBS) solution. For light microscopy, fixed tissues were dehydrated in an ascending series of ethanol, cleared in xylene, and embedded in paraffin. Five-micrometer thick sections were mounted in slides previously treated with 3-aminopropyltriethoxysilane (Sigma-Aldrich, St. Louis, MO) and stained with hematoxylin-eosin for preliminary observation.

\section{Immunohistochemistry}

Details and concentration of the antibodies used are summarized in Table 1. Each antibody was assayed in at least five sections of each ovary from each individual. The streptavidin-biotin immunoperoxidase method was done as previously described (Ortega et al. 2004, Salvetti et al. 2004b). In brief, sections were deparaffinized and hydrated, and given microwave pretreatment (antigen retrieval). The endogen peroxidase activity was inhibited with $1 \% \mathrm{H}_{2} \mathrm{O}_{2}$ and nonspecific binding was blocked with $10 \%$ normal goat serum. All sections were incubated with the primary antibodies for $18 \mathrm{~h}$ at $4{ }^{\circ} \mathrm{C}$ and then for $30 \mathrm{~min}$ at room temperature with rat-preabsorbed biotinylated secondary antibodies selected specifically to each of the two types of primary antibodies used (monoclonal or polyclonal). The visualization of antigens was achieved by the streptavidin-peroxidase method 
Table 1. Used antibodies, suppliers and dilutions.

\begin{tabular}{|c|c|c|c|}
\hline Antibodies & Clone & Supplier & Dilution \\
\hline \multicolumn{4}{|l|}{ Primary antibodies } \\
\hline Vimentin (VIM) & V9 & Zymed & Prediluted \\
\hline Cytokeratins (1/5/6/8/10/14/18) (CKs) & LP $34,34 \beta E 12 \& 35 \beta \mathrm{H} 11$ & Dako & Prediluted \\
\hline pan-Cadherin (GFAP) & Polyclonal & Zymed & $1: 50$ \\
\hline Proliferation cellular nuclear antigen (PCNA) & $\mathrm{PC} 10$ & Novocastra & $1: 200$ \\
\hline \multicolumn{4}{|l|}{ Secondary antibodies } \\
\hline Anti-rabbit $\operatorname{Ig} G$ & Polyclonal & Zymed & $1: 300$ \\
\hline Anti-mouse $\operatorname{Ig} G$ & Polyclonal & Chemicon & $1: 120$ \\
\hline
\end{tabular}

(BioGenex, San Ramon, CA) and 3.3-diaminobenzidine (Liquid DAB-Plus Substrate Kit - Zymed, San Francisco, CA) was used as chromogen. Finally, the slides were washed in distilled water and counterstained with Mayer's hematoxylin, dehydrated, and mounted. To verify specificity, adjacent control sections were subjected to the same immunohistochemical method, replacing primary antibodies by rabbit and mouse nonimmune serum.

\section{Image Analysis}

Image analysis was performed using Image ProPlus 3.0.1® system (Media Cybernetics, Silver Spring, MA, USA). Images were digitized by a CCD color video camera (Sony, Montvale, NJ, USA) mounted on top of a conventional light microscope (Olympus BH-2, Olympus Co., Japan) using $\times 4, \times 10$, and $\times 40$ objective lenses. Microscopic fields covering the entire follicular wall area were digitized and stored in a 24-bit true color TIFF format.

Follicular mean diameter and the granulosa and theca thickness were analyzed using specific tools of the software. The immunohistochemical stained area (IHCSA) was calculated as a percentage of total area, assessed by color segmentation analysis, which produces quantification by locating all objects of a specific color (brown stain). The images were then transformed to a bilevel scale TIFF format (Salvetti et al. 2004b). The IHCSA (black area) was calculated from at least 25 images of each area (granulosa, theca externa, and theca interna) in each slide.

\section{Hormone assays}

Follicle-stimulating hormone (FSH) and LH serum levels were determined by radioimmunoassay (RIA) using the kit provided by NIDDK (USA) as previously described (Ortega et al. 2004). Intra- and inter-assay coefficients of variation for $\mathrm{LH}$ and $\mathrm{FSH}$ were less than $8 \%$ and $12 \%$, respectively. Minimum detectable concentrations were 0.16 and $1.18 \mathrm{ng} \mathrm{ml}^{-1}$ of serum for $\mathrm{LH}$ and FSH, respectively.

Serum estradiol and progesterone were estimated by RIA using highly specific antiserum provided by Dr. G.D. Niswender (NIDDK) (Korenman et al. 1974). Labeled hormones were purchased from Amersham (UK). Assay sensitivity for estradiol was $1.7 \mathrm{pg}$ and intraand interassay coefficients of variation were $9.3 \%$ and $11.4 \%$, respectively. Assay sensitivity for progesterone was $50 \mathrm{pg}$ and intra- and inter-assay coefficients of variation were $7.5 \%$ and $11.9 \%$, respectively (ChamsonReig et al. 1999).

After ethyl-ether extraction, the serum testosterone was determined by RIA using a specific antiserum provided by Dr. G.D. Niswender (NIDDK). Labeled hormone was purchased from New England Nuclear (Boston, MA, USA). Assay sensitivity: the lowest point in the testosterone standard curve was $12.5 \mathrm{pg}$ and the lowest detectable concentration when extracting $150 \mu \mathrm{l}$ serum was $208.3 \mathrm{pg} / \mathrm{ml}$. Intra- and interassay coefficients of variation were $7.8 \%$ and $12.3 \%$, respectively (Bianchi et al. 2004).

Corticosterone concentration was determined by extracting $25 \mu \mathrm{l}$ of serum sample with $1 \mathrm{ml}$ of dichlormethane (Merck, Westpoint, PA, USA). The solvent was decanted and dried at $50{ }^{\circ} \mathrm{C}$. Fifty microliters of 1-alpha-2-alpha- $\mathrm{N}\left({ }^{3} \mathrm{H}\right)$ corticosterone (Amersham, UK; $10000 \mathrm{cpm}$ approximately) were diluted with $200 \mu \mathrm{l}$ of standard solutions or unknown samples and $50 \mu \mathrm{l}$ of anticorticosterone rabbit serum. The tubes were incubated overnight at $4{ }^{\circ} \mathrm{C}$ and the separation of bound and free hormone fractions was achieved by the addition of $100 \mu \mathrm{l}$ of charcoal (1 g \%)-dextran (0.1 g \%) suspension. Bound 
Table 2. Histomorphometric analysis of follicular wall of ovaries in control and treated rats*.

\begin{tabular}{lllll}
\hline & C-P & L & EV & ACTH \\
\hline Follicle mean diameter & $526.45 \pm 32.53^{\mathrm{a}}$ & $765.37 \pm 29.56^{\mathrm{b}}$ & $684.79 \pm 48.98^{\mathrm{b}}$ & $561.31 \pm 25.33^{\mathrm{a}}$ \\
Granulosa thickness & $55.42 \pm 5.24^{\mathrm{a}}$ & $62.46 \pm 10.09^{\mathrm{a}}$ & $33.04 \pm 4.17^{\mathrm{b}}$ & $63.00 \pm 2.50^{\mathrm{a}}$ \\
Theca interna thickness & $14.17 \pm 1.24^{\mathrm{a}}$ & $16.04 \pm 1.66^{\mathrm{a}}$ & $9.94 \pm 0.74^{\mathrm{b}}$ & $16.08 \pm 1.70^{\mathrm{a}}$ \\
Theca extrena thickness & $11.80 \pm 1.01$ & $10.65 \pm 1.38$ & $11.57 \pm 1.34$ & $8.79 \pm 0.86$ \\
\hline
\end{tabular}

${ }^{*}$ Values represent mean \pm SEM $(\mu \mathrm{m})$. Different letters within a row indicate significant differences $(p<0.05)$

Table 3. Distribution of immunoreactivity in the follicular wall of ovaries in controls and treated rats.

\begin{tabular}{|c|c|c|c|c|}
\hline & C-P & $\mathbf{L}$ & EV & АСТН \\
\hline \multicolumn{5}{|l|}{ Vimentin } \\
\hline Granulosa & $7.76 \pm 0.46^{\mathrm{a}}$ & $30.62 \pm 2.48^{b}$ & $23.70 \pm 3.23^{c}$ & $8.90 \pm 2.01^{\mathrm{a}}$ \\
\hline Theca interna & $5.98 \pm 0.64$ & $5.62 \pm 0.76$ & $7.32 \pm 2.47$ & $4.40 \pm 1.13$ \\
\hline Theca externa & $2.29 \pm 0.28^{\mathrm{a}}$ & $2.31 \pm 0.45^{\mathrm{a}}$ & $6.32 \pm 1.66^{b}$ & $2.94 \pm 0.89^{a}$ \\
\hline \multicolumn{5}{|l|}{ Cytokeratins } \\
\hline Granulosa & $0.94 \pm 0.20^{\mathrm{a}}$ & $19.96 \pm 1.48^{b}$ & $15.28 \pm 2.00^{\mathrm{c}}$ & $1.19 \pm 0.44^{\mathrm{a}}$ \\
\hline Theca interna & - & - & - & - \\
\hline Theca externa & - & - & - & - \\
\hline \multicolumn{5}{|l|}{ Pan-Cadherin } \\
\hline Granulosa & $11.02 \pm 1.44^{\mathrm{a}}$ & $26.74 \pm 2.04^{b}$ & $31.14 \pm 4.13^{b}$ & $9.76 \pm 3.06^{\mathrm{a}}$ \\
\hline Theca interna & $5.88 \pm 0.47^{\mathrm{a}}$ & $16.96 \pm 2.27^{b}$ & $14.38 \pm 1.44^{b}$ & $6.61 \pm 2.37^{\mathrm{a}}$ \\
\hline Theca externa & $0.43 \pm 0.28$ & $0.65 \pm 0.17$ & $0.60 \pm 0.19$ & $0.53 \pm 0.17$ \\
\hline \multicolumn{5}{|l|}{$P C N A$} \\
\hline Granulosa & $8.29 \pm 0.76^{\mathrm{a}}$ & $2.34 \pm 0.54^{b}$ & $1.72 \pm 0.26^{b}$ & $6.89 \pm 0.96^{\mathrm{a}}$ \\
\hline Theca interna & $9.49 \pm 0.76^{\mathrm{a}}$ & $2.08 \pm 0.62^{b}$ & $0.76 \pm 0.17^{b}$ & $8.15 \pm 0.99^{a}$ \\
\hline Theca externa & $3.53 \pm 0.64^{\mathrm{a}}$ & $1.01 \pm 0.31^{\mathrm{b}}$ & $0.38 \pm 0.13^{b}$ & $3.30 \pm 0.54^{a}$ \\
\hline
\end{tabular}
${ }^{*}$ Values represent mean immunohistochemical stained area (IHCSA) \pm SEM. Different letters within a row indicate significant
differences $(p<0.05)$

radioactivity was determined in an LKB $\beta$-counter. The intra- and inter-assay coefficients of variation ranged between 4-7 \%, and 8-10\%, respectively (Spinedi et al. 1991).

\section{Statistics}

A statistical software package (SPSS 11.0 for Windows, SPSS Inc., Chicago, IL, USA) was used for performing the statistical tests. The statistical significance of differences was assessed by one-way ANOVA, followed by Duncan's multiple range test as a multiple comparison test. $P<0.05$ values were considered significant. Results were expressed as mean \pm SEM.

\section{Results}

Estrous cycles

The animals in the control group showed normal cycles during the whole experiment. In the constant lightexposed group, all animals showed irregular cycles within 3 weeks and PVC within 13 weeks of permanent light exposure. In the EV-treated group, all animals displayed irregular cycles within 1 week of EV treatment and most (90\%) showed PVC by 3 weeks after injection. In the ACTH group, all animals showed irregular cycles during the whole experience. 

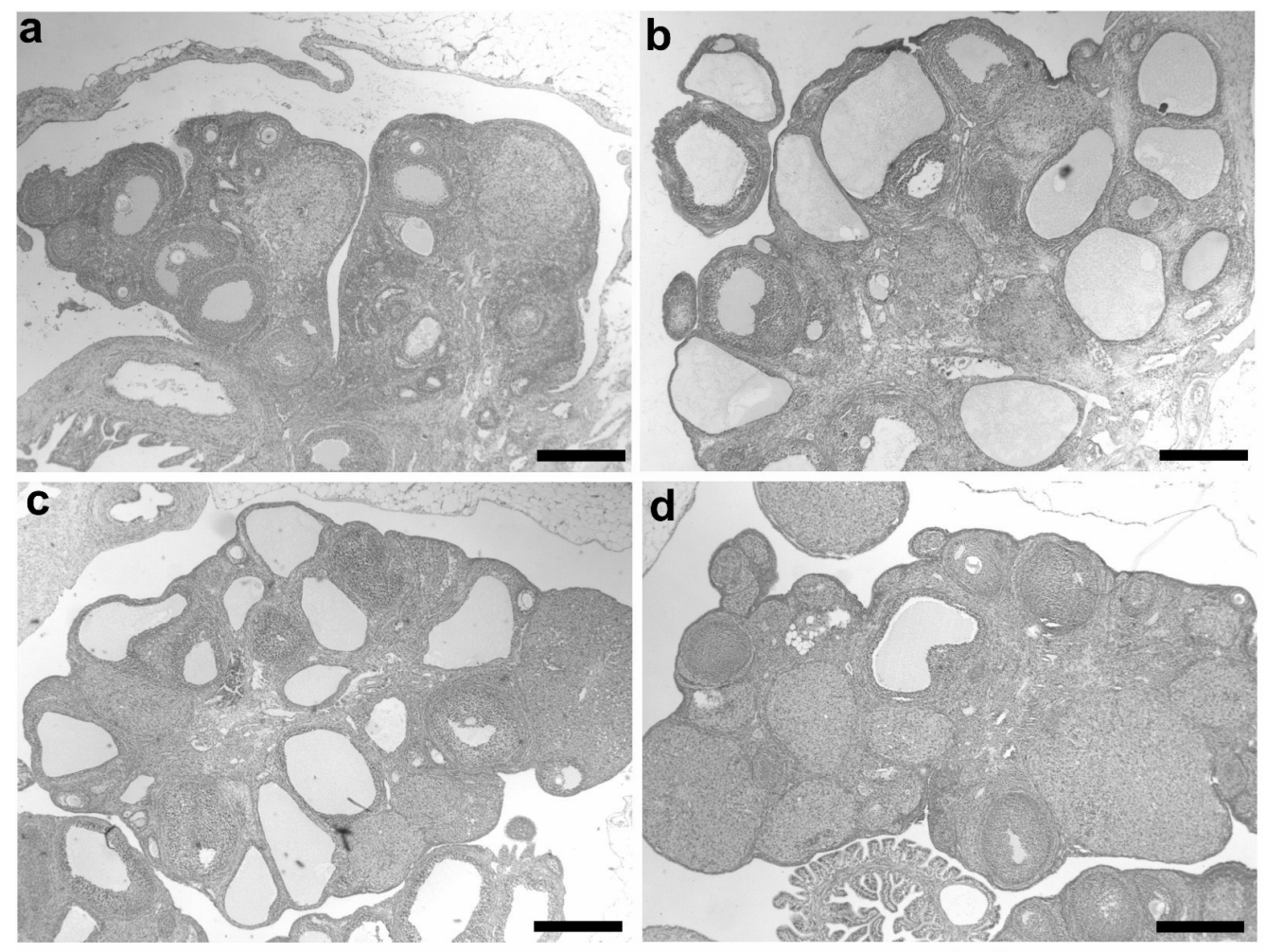

$\mathbf{e}$

f

g

h
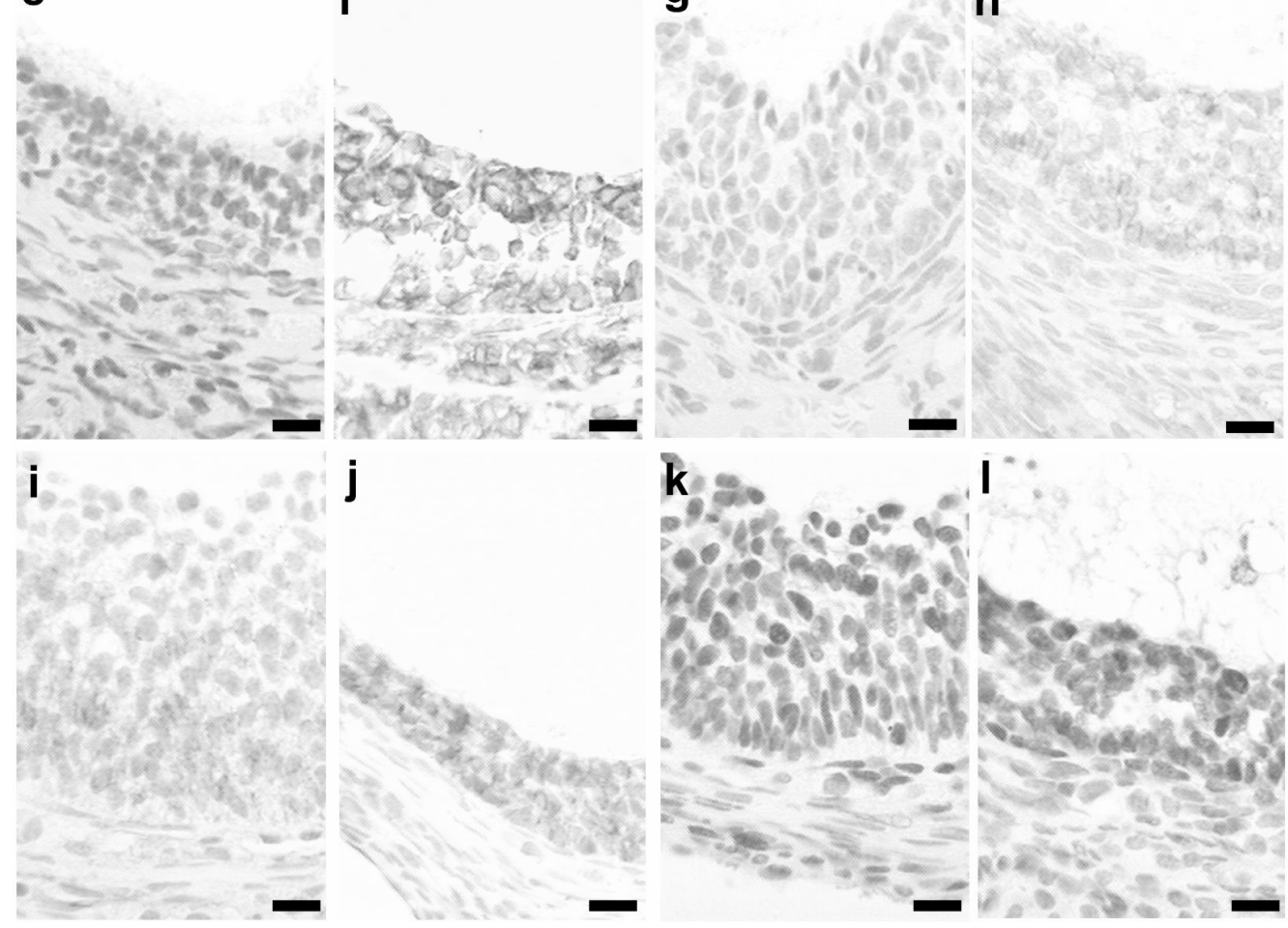

Fig. 1. Sections of ovaries from control (proestrous) $(a, e, g, i, k)$, constant light-exposed $(b, f, h)$, estradiol valerate-treated $(c, j, l)$ and ACTH treated $(d)$ rats staining with hematoxylin-eosin $(a, b, c, d)$ and immunostaining with vimentin $(e, f)$, cytokeratins $(g, h)$ and PCNA $(\mathrm{k}-\mathrm{l})$ antibodies. a-d bars $=500 \mu \mathrm{m}$; e-l bars $=20 \mu \mathrm{m}$.

\section{Morphology}

Ovaries from the control group exhibited follicles in various stages of development. Preovulatory tertiary follicles and growing secondary follicles were observed in proestrous, whereas only secondary follicles and fresh corpora lutea were seen in diestrous. Primordial, primary, and atretic follicles, as well as interstitial glands, were found in both control groups. In 
constant light-exposed animals, small follicles in early development were observed, in addition to follicles showing evidence of atresia, and many large cysts with thickened granulosa cell layer or large cystic follicles with scant granulosa cells. Corpus luteum was absent and hyperplasia of interstitial glands was observed. The ovaries of EV-treated animals showed follicular cysts, although primary and early secondary follicles were present. There was a conspicuous absence of both large secondary and tertiary follicles as well as corpus luteum. In ACTH-treated animals, the ovarian morphology was similar to the control animals.

\section{Histomorphometry}

Histomorphometric results are listed in Table 2. The average diameter of cystic follicles was significantly higher in constant light-exposed and EV-treated rats. The thickness of granulosa, theca interna, and theca externa did not show significant differences among C-P, C-D, L, or ACTH groups. In the EV-treated rats, a significant reduction in the thickness of the granulosa and theca interna was evident.

\section{Immunohistochemistry}

A summary of the immunohistochemical (IHCSA) expression for the different antibodies is given in Table 3 and Figure 1. The granulosa cell layer of cystic follicles in the L and EV groups had a significantly greater IHCSA for vimentin than the C-P and ACTH antral follicles. The theca interna cells in C-P ovaries, similarly as in the treated ovaries, showed a moderate positive immunostaining without differences in the IHCSA. Some theca externa cells showed weak staining in all follicles studied, and a higher IHCSA was observed in EV-treated rats.

Cytokeratins (CKs) showed a low expression in the granulosa cells of antral follicles in the C-P and ACTH-treated animals, whereas in granulosa cells of cystic follicles, L and EV groups showed significantly higher IHCSA. No immunostaining was detected in theca cells.

Immunostaining for p-cadherins was observed in the granulosa and theca interna of cystic follicles ( $\mathrm{L}$ and EV groups) and weak and irregular immunostaining was seen in the theca externa.

Cellular proliferation, evaluated through the expression of proliferating cell nuclear antigen (PCNA), showed a high index in the whole follicular wall in antral follicles of C-P and ACTH. This was significantly decreased in $\mathrm{L}$ and $\mathrm{EV}$ groups.

\section{Hormone levels}

Hormone serum levels are shown in Figure 2. The three treatments induced a significant reduction in LH and FSH levels as compared to C-P animals. Estradiol serum levels in EV-treated and $\mathrm{L}$ animals showed significant increments, while in ACTH-treated animals, the levels were similar to those of proestrous animals. The levels of progesterone in the treated animals were similar to those of proestrous animals. Testosterone serum concentrations varied with a significant reduction in $\mathrm{L}$ and $\mathrm{EV}$ animals in relation to C-D. Corticosterone showed an increase in the ACTH group and a significant reduction in the EV group.

\section{Discussion}

Why and how ovaries become polycystic have been the subject of considerable speculation as well as the object of meticulous studies with different approaches (Barberi 1991, Agarwal and Shankar 1998, Hoo and Shaw, 2005, Raja et al. 2005). Nevertheless, little is known about the mechanisms that cause their development. The etiology and pathogenesis of follicular cysts have been the subject of numerous hypotheses since the middle of the 19th century. However, to this day, they are still not completely clarified either in humans or in animals (Barberi 1991, Hamilton et al. 1995, Garverick 1997, Silvia et al. 2002, Peter 2004).

In this work, both L and EV groups develop polycystic ovaries. The hormonal levels; vimentin, CKs, and cadherins immunoexpression; and follicular wall morphometry differed markedly from those of the control group, indicating that polycystic ovaries do not define a single disorder, but rather a general class of conditions encompassing a variety of individual expressions.

In this sense, the PCOS has been considered a progressive multiglandular endocrinopathy where the delicate balance of the hypothalamic-pituitary-adrenalovarian axis is disturbed, resulting in a failure of the cyclic reproductive mechanism (Mahesh et al. 1987, Hamilton et al. 1995). A total loss of the cyclic reproductive changes appears to follow a phase of irregular rhythmicity in rats experimental PCOS (Salvetti et al. 2004a). 

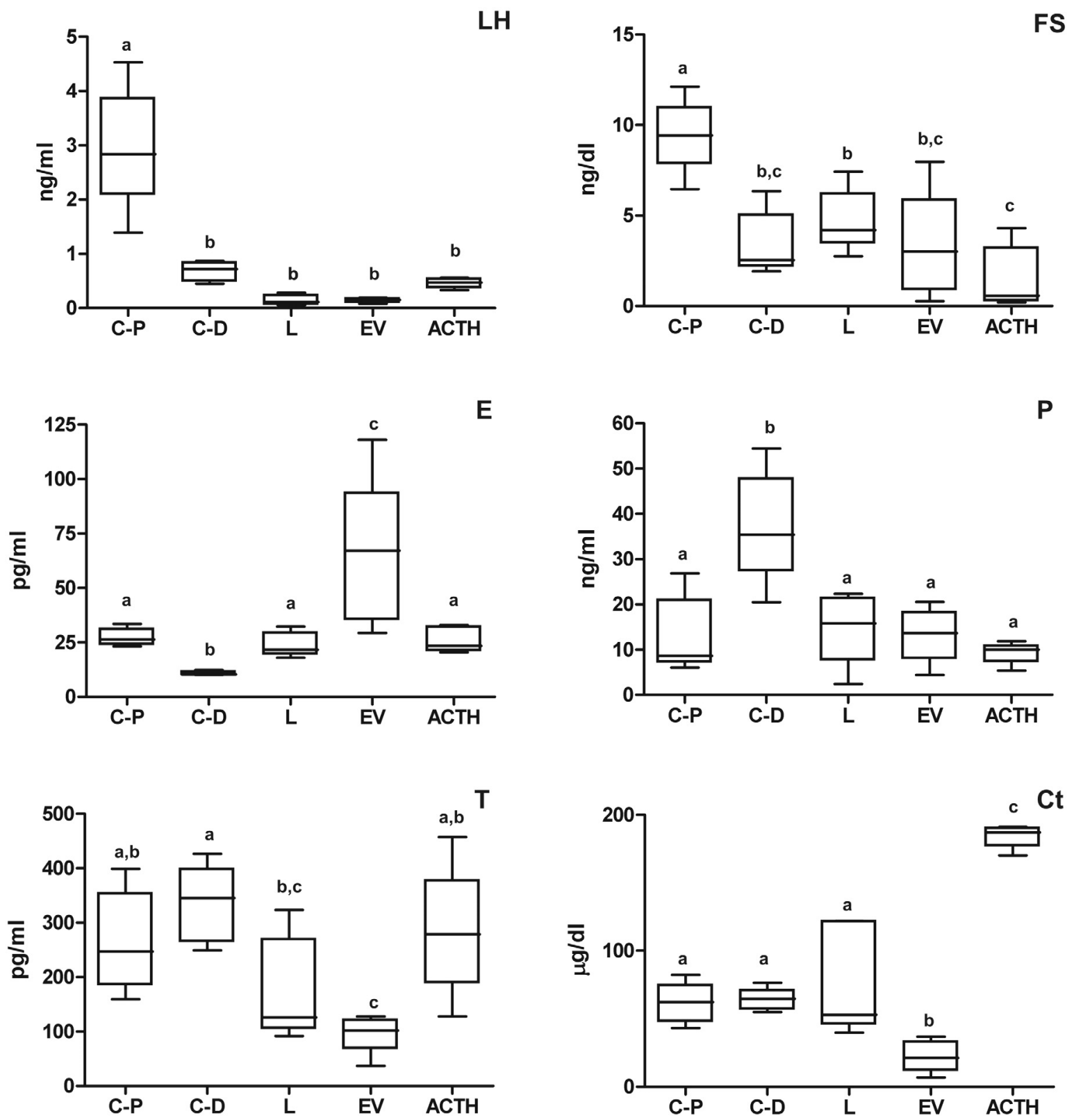

Fig. 2. Medial values, interquartile intervals (box) and range (whiskers) for $L H, F S H$, estradiol $(E)$, progesterone $(P)$, testosterone $(T)$ and corticosterone $(\mathrm{Ct})$ in control-proestrous (C-P), control-diestrous (C-D), constant light-exposed (L), estradiol valerate-treated (EV) and ACTH treated $(A C T H)$ rats. Different letters indicate statistical differences $(p<0.05)$.

\section{Ovarian changes}

Ovarian morphology provides both a convenient and appropriate measurement to describe cystic status as differences were found in the morphometric characteristics, and presence or absence of follicular cyst and corpus luteum. On the other hand, we have recently described changes that occur in the expression of vimentin and CKs in the ovary of rats with ovarian cysts, which are probably due to structural and functional modifications that occur during cystogenesis (Salvetti et al. 2004b). The present study demonstrates a similar pattern of expression of these proteins in cystic follicles and confirms the absence of cellular changes in the follicular wall of ACTH-treated animals.

Numerous lines of evidence suggest that important growth-related cellular functions such as cell proliferation, expression of differentiated phenotype, response to tissue-specific hormones, and tissue 
morphogenesis are modulated through changes in cellular shape (Ben-Ze'Ev and Amsterdam 1987, Marettova and Maretta 2002). Since cytoskeletal elements are responsible for determining cell morphology and shape, this study about cytoskeletal-related protein expression was directed towards investigating the possible existence of a relation between their immunolocalization and the organization of the follicular wall in follicular cysts. The occurrence of vimentin-containing granulosa cells has been related to mitotic activity, and with follicular atresia and dedifferentiation associated with loss of cell-to-cell contact (Raymond and Leong 1989, Van den Hurk et al. 1995). However, if cell proliferation activity in the granulosa and theca interna layers is considered to decrease in association with the induction of follicular cysts, the changes in vimentin expression observed would be due to cellular dedifferentiation. The idea that an increase in intermediate filaments is a degenerative change is also supported by their increase reported in many papers (Ghadially et al. 1978, Pieraggi et al. 1984).

Cell adhesion molecules (cadherins) have been identified in the ovaries and linked with cyclic remodeling. Although cadherin proteins have been identified in cells of developing follicles and corpora lutea, their role in ovarian function is unclear (Machell and Farookhi 2003). There is evidence that cadherins contribute to the structural integrity of follicles and corpora lutea. For example, in atretic pig follicles, the loss of granulosa cell adhesion and follicle wall integrity is associated with a significant decrease in the expression of E-cadherin by granulosa cells (Ryan et al. 1996). Likewise, a similar decrease in E-cadherin protein has been reported in baboon regressing corpora lutea during the late luteal phase of the reproductive cycle (KhanDawood et al. 1996). Our results agree with data that suggest that disturbances in ovarian cell adhesion in vivo are linked with increased atresia, cyst formation, and insufficient luteal function (Khan-Dawood et al. 1996, Makrigiannakis et al. 1999). In vitro studies indicate that cell-cell communication and aggregation are important for the differentiation of rat granulosa cells by enhancing FSH induction of both aromatase and LH receptors (Farookhi and Desjardins 1986).

Cystic follicles showed extremely low PCNA reaction in the granulosa and theca cell layers, compared with healthy follicles, confirming the findings in cows with ovarian cystic disease (Isobe and Yoshimura 2000). These suggest that the disorder of cell proliferation is also associated with the occurrence of follicular cysts in rats.

\section{Endocrinological aspects}

Although the exact mechanism involving the hypothalamic-pituitary-axis in the PCOS still has to be elucidated, it should be noted that closely related neuroendocrine mechanisms are involved in the cyclic release of ACTH and gonadotropins. In addition, there is evidence from both in vitro perfusions and in vivo experiments to show that exogenously increased ACTH concentrations or stress reduce the amount of $\mathrm{LH}$ released. In domestic ruminants, treatment with ACTH resulted in a reduction of pulsatile LH secretion and in the abolition of LH surge without changes in the secretion of FSH. In fact, FSH ability to stimulate follicular emergence remains despite the development of PCOS (Ribadu et al. 2000). Cows with ovarian follicular cysts frequently have an abnormal, intermediate concentration of progesterone (Hatler et al. 2003). Even at these low concentrations of progesterone, the preovulatory surge of LH and subsequent ovulation can be blocked resulting in the persistence of ovulatory size follicles (Duchens et al. 1994). One possible source of this progesterone is the adrenal gland, due to treatment of cows with ACTH-induced rapid secretion of progesterone (Verkerk et al. 1994, Silvia et al. 2005). However, in adrenalectomized rats subjected to stress, there was a decrease in LH level and an increase in progesterone (Galvez et al. 1999). Thus, these hormonal changes could represent a reflex action of an extra-adrenal mechanism.

Our results demonstrate that rats respond to ACTH administration with an elevation of corticosterone and reduction in LH and FSH (compared with proestrous levels), but without changes in the levels of other hormones or in ovarian morphology. Stener-Victorin et al. (2005) have suggested a metabolic shift toward corticosterone synthesis and secretion, and a hyperadrenal state in EV-induced PCOS. However, our results clearly indicate that the EV-induced PCOS is not associated with a hyperadrenal state, because we have found a decrease in corticosterone without changes in progesterone. Therefore, there was no evidence to show that basal adrenal activity differed between constantly light-induced PCOS and control rats.

In this sense, although some researchers postulated that constant light acts on the release of ACTH (Singh 1969), we have shown in present report that the constant light-induced PCOS takes place without a significant increase in the corticosterone levels (an index for adrenal activity and ACTH stimulation) (Colak et al. 2002, Tsilchorozidou et al. 2003, Silvia et al. 2005). This 
is supported by a recent study that points to the participation of the pineal gland, but not the adrenal gland, in the pathogenesis of constant light-induced PCOS (Prata Lima et al. 2004). These authors showed that the ovarian morphology in PCOS induced in rats by pinealectomy is similar to that induced by constant light exposure. They also demonstrated that in both cases, the development of ovarian cysts and anovulation could be inhibited by melatonin administration. In this sense, melatonin acts on the central nervous system of the rodent, with an antigonadotropic action in the anterior hypothalamus (Reichlin 1992, Prata Lima et al. 2004).

However, it is interesting to mention that Paredes et al. (1998) showed that the exposure to stress can represent an etiological factor in the genesis of PCOS in rats. In this work, the effect on the ovarian function of exposure to 3 weeks of stress was not maintained for 11 weeks. The temporal disruption of ovulation, observed by these authors, appears to be the consequence of a poorly controlled ovarian function under increased sympathetic nerve activity. The increase in norepinephrine release after 3 weeks of stress correlates with ovarian cyst formation, and the decrease in the release found at 11 weeks of stress correlates with the recovery of ovarian function to control level (Paredes et al. 1998).

Among the uncertainties surrounding the etiology of the PCOS in women, the role of altered cortisol metabolism has become prominent (Tsilchorozidou et al. 2003). Enhanced 5 $\alpha$-reductase, deregulation of $11 \beta$-hydroxysteroid dehydrogenase type 1 activity, and increased total adrenal steroid production rates have been previously described in PCOS and implicated as possible pathogenetic mechanisms. However, in normal women, circulating adrenal androgen levels and their response to ACTH are highly individualized and genetically predetermined (Rotter et al. 1985, Azziz et al. 1999). Supporting this concept, various investigators have observed a significant degree of heritability for adrenal androgen levels with an increased risk for developing PCOS (Ibanez et al. 1993, Thomas et al. 1994, Nafziger et al. 1998, Yildiz et al. 2004). Recently, Silvia et al. (2005) have reported that the naturally occurring cystic condition in cows is not associated with abnormalities in adrenal secretion of either cortisol or progesterone. These results suggest that adrenal dysfunction could act as an inheritable risk factor, although this is not the only one in the pathogenesis of PCOS (Xita et al. 2002, Silvia et al. 2002, Peter, 2004).

In conclusion, treatment with $\mathrm{ACTH}$ in rats resulted in corticosterone stimulation with $\mathrm{LH}$ reduction but not changes in ovarian morphology. Although stress (or ACTH) stimulation and adrenal hyperactivity may be only one pathophysiological mechanism involved in follicular cyst pathogenesis in other species, we have not found important evidence to support that this happens in rats.

\section{Acknowledgments}

We are very grateful to Schering (Buenos Aires, Argentina) and ELEA (Buenos Aires, Argentina) laboratories for providing us with the drugs. We thank the National Hormone and Pituitary Program of the National Institute of Diabetes and Digestive and Kidney Diseases (NIH, USA) and Dr. A. F. Parlow for the RIA kits and to Dr. Damasia Becu-Villalobos and Eduardo Spinedi (CONICET, Argentina) for valuable RIA contribution. H.H.O. is a Research Career Member of the National Scientific Research Council (CONICET, Argentina).

\section{References}

AGARWAL SK, SHANKAR U: Clinical response, related progesterone profile and subsequent fertility after gonadotropin releasing hormone administration in crossbred cows with ovarian cyst. Ind Vet J 75: 127-130, 1998.

AZZIZ R, BLACK VY, KNOCHENHAUER ES, HINES GA, BOOTS LR: Ovulation after glucocorticoid suppression of adrenal androgens in the polycystic ovary syndrome is not predicted by the basal dehydroepiandrosterone sulfate level. J Clin Endocrinol Metab 84: 946-950, 1999.

BARBERI RL: Polycystic ovarian disease. Annu Rev Med 42: 199-204, 1991.

BEN-ZE'EV A, AMSTERDAM A: In vitro regulation of granulosa cell differentiation J Biol Chem 262: 5366-5376, 1987. 
BIANCHI MS, CATALANO PN, BONAVENTURA MM, SILVEYRA P, BETTLER B, LIBERTUN C, LUXLANTOS VA: Effect of androgens on sexual differentiation of pituitary gamma-aminobutyricacid receptor subunit GABA (B) expression. Neuroendocrinology 80: 129-142, 2004.

CHAMSON-REIG A, BIANCHI MS, REY-ROLDAN E, SORIANELLO E, LIBERTUN C, LUX-LANTOS VA: Development of an experimental ovarian tumor over a year in the rat. Life Sci 65: 1275-1285, 1999.

COLAK R, KELESTIMUR F, UNLUHIZARCI K, BAYRAM F, SAHIM Y, TUTUS A: A comparison between the effects of low dose $(1 \mu \mathrm{g})$ and standard dose $(250 \mu \mathrm{g})$ ACTH stimulation tests on adrenal P450c17alpha enzyme activity in women with polycystic ovary syndrome. Eur J Endocrinol 147: 473-477, 2002.

DOBSON H, RIBADU AY, NOBLE KM, TEBBLE JE, WARD WR: Ultrasonography and hormone profiles of adrenocorticotrophic hormone (ACTH)-induced persistent ovarian follicles (cysts) in cattle. J Reprod Fertil 120: 405-410, 2000.

DUCHENS M, FORSBERG M, EDQVIST L-E, GUSTAFSSON H, RODRIGUEZ-MARTINEZ H: Effect of suprabasal progesterone levels around estrus on plasma concentrations of progesterone, estradiol-17 $\beta$ and LH in heifers. Theriogenology 42: 1159-1169, 1994.

FAROOKHI R, DESJARDINS J: Luteinizing hormone receptor induction in dispersed granulosa cells requires estrogen. Mol Cell Endocrinol 47: 13-24, 1986.

FAROOKHI R, HEMMINGS R, BRAWER JR: Unilateral ovariectomy restores ovulatory cyclicity in rats with a polycystic ovarian condition. Biol Reprod 32: 530-540, 1985.

FRASER TB, TURNER SW, MANGOS GJ, LUDBROOK J, WHITWORTH JA: Comparison of telemetric and tailcuff blood pressure monitoring in adrenocorticotrophic hormone-treated rats. Clin Exp Pharmacol Physiol 28: 831-835, 2001.

GALVEZ A, PAREDES A, FIEDLER JL, VENEGAS M, LARA HE: Effects of adrenalectomy on the stress-induced changes in ovarian sympathetic tone in the rat. Endocrine 10: 131-135, 1999.

GARVERICK HA: Ovarian follicular cysts in dairy cows. J Dairy Sci 80: 995-1004, 1997.

GHADIALLY FN, LALONDE JM, DICK CE: A mechanism of formation of desmosome-like structures between synovial intimal cells. Experientia 34: 1212-1213, 1978.

HAMILTON SA, GARVERICK HA, KEISLER DH, XU ZZ, LOOS K, YOUNGQUIST RS, SALFEN BE: Characterization of ovarian follicular cysts and associated endocrine profiles in dairy cows. Biol Reprod 53: 890-898, 1995.

HATLER TB, HAYES SH, LARANJA DA FONSECA LF, SILVIA WJ: Relationship between endogenous progesterone and follicular dynamics in lactating dairy cows with ovarian follicular cysts. Biol Reprod 69: 218223, 2003.

HOO P, SHAW R: The patient with polycystic ovary syndrome. Practitioner 249: 555-557, 2005.

IBANEZ L, POTAU N, VIRDIS R, ZAMPOLLI M, TERZI C, GUSSINYE M, CARRASCOSA A, VICENS-CALVET E: Postpubertal outcome in girls diagnosed of premature pubarche during childhood: increased frequency of functional ovarian hyperandrogenism. J Clin Endocrinol Metab 76: 1599-1603, 1993.

ISOBE N, YOSHIMURA Y: Immunocytochemical study of cell proliferation in the cystic ovarian follicles in cows. Theriogenology 54: 1159-1169, 2000.

KHAN-DAWOOD FS, DAWOOD MY, TABIBZADEH S: Immunohistochemical analysis of the microanatomy of primate ovary. Biol Reprod 54: 734-742, 1996.

KITAMURA Y, ARAKI H, GOMITA Y: Influence of ACTH on the effects of imipramine, desipramine and lithium on duration of immobility of rats in the forced swim test. Pharmacol Biochem Behav 71: 63-69, 2002.

KORENMAN SG, STEVENS RH, CARPENTER LA, ROBB M, NISWENDER GD, SHERMAN BM: Estradiol radioimmunoassay without chromatography: procedure, validation and normal values. J Clin Endocrinol Metab 388: 718-720, 1974.

MACHELL NH, FAROOKHI R: E- and N-cadherin expression and distribution during luteinization in the rat ovary. Reproduction 125: 791-800, 2003.

MAHAJAN DK: Polycystic ovarian disease: animal models. Endocrinol Metab Clin 17: 705-732, 1988. 
MAHESH VB, MILLS TM, BAGNELL CA, CONWAY BA: Animal models for study of polycystic ovaries and ovarian atresia. In: Regulation of Ovarian and Testicular Function. VB MAHESH, DS DHINDSA, E ANDERSON, SP KALRA (eds), Plenum, New York, 1987, pp 237-258.

MAKRIGIANNAKIS A, COUKOS G, CHRISTOFIDOU-SLOLOMIDOU M, GOUR BJ, RADICE GL, BLASCHUK O, COUTIFARIS C: N-cadherin-mediated human granulosa cell adhesion prevents apoptosis: a role in follicular atresia and luteolysis? Am J Pathol 154: 1391-1406, 1999.

MARETTOVA E, MARETTA M: Demonstration of intermediate filaments in sheep ovary. Acta Histochem 104: 431434, 2002.

NAFZIGER AN, BOWLIN SJ, JENKINS PL, PEARSON TA: Longitudinal changes in dehydroepiandrosterone concentrations in men and women. J Lab Clin Med 131: 316-323, 1998.

NATIONAL RESEARCH COUNCIL: Guide for the Care and Use of Laboratory Animals. National Academy Press, Washington, 1996.

ORTEGA HH, LORENTE JA, MIRA GA, BARAVALLE C, SALVETTI NR: Constant light exposure cause dissociation in gonadotropins secretion and inhibits partially neuroendocrine differentiation of Leydig cells in adult rats. Reprod Domest Anim 39: 417-423, 2004.

PAREDES A, GALVEZ A, LEYTON V, ARAVENA G, FIEDLER JL, BUSTAMANTE D, LARA HE: Stress promotes development of ovarian cysts in rats: the possible role of sympathetic nerve activation. Endocrine 8: 309-315, 1998.

PETER AT: An update on cystic ovarian degeneration in cattle. Reprod Domest Anim 39: 1-7, 2004.

PHOGAT JB, SMITH RF, DOBSON H: Effect of adrenocorticotrophic hormone on gonadotrophin releasing hormoneinduced luteinizing hormone secretion in vitro. Anim Reprod Sci 48: 53-65, 1997.

PIERAGGI MT, JULIAN M, BOUISSOU H: Fibroblast changes in cutaneous ageing. Virchows Arch A Pathol Anat Histopathol 402: 275-287, 1984.

PRATA LIMA MF, BARACAT EC, SIMOES MJ: Effects of melatonin on the ovarian response to pinealectomy or continuous light in female rats: similarity with polycystic ovary syndrome. Braz J Med Biol Res 37: 987-995, 2004.

RAJA A, HASHMI SN, SULTANA N, RASHID H: Presentation of polycystic ovary syndrome and its management with clomiphene alone and in combination with metformin. J Ayub Med Coll Abbottabad 17: 50-53, 2005.

RAYMOND WA, LEONG AS: Vimentin, a new prognostic parameter in breast carcinoma? J Pathol 158: 107-114, 1989.

REICHLIN S: The pineal gland. In: Williams Textbook of Endocrinology. JD WILSON, D FOSTER (eds), WB Saunders, Philadelphia, 1992, pp 240-253.

RIBADU AY, NAKADA K, MORIYOSHI M, ZHANG WC, TANAKA Y, NAKAO T: The role of LH pulse frequency in ACTH-induced ovarian follicular cysts in heifers. Anim Reprod Sci 64: 21-31, 2000.

ROTTER JI, WONG FL, LIFRAK ET, PARKER LN: A genetic component to the variation of dehydroepiandrosterone sulfate. Metabolism 34: 731-736, 1985.

RYAN PL, VALENTINE AF, BAGNELL CA: Expression of epithelial cadherin in the developing and adult pig ovary. Biol Reprod 55: 1091-1097, 1996.

SALVETTI NR, GIMENO EJ, CANAL AM, LORENTE JA, ORTEGA HH: Histochemical study of the extracellular matrix components in the follicular wall of induced polycystic ovaries. Braz J Morphol Sci 20: 3-10, 2003.

SALVETTI N, CANAL AM, GIMENO EJ, ORTEGA HH: Polycystic ovarian syndrome: temporal characterization of the induction and reversion process in an experimental model. Braz J Vet Res Anim Sci 41: 389-395, 2004a.

SALVETTI NR, GIMENO EJ, LORENTE JA, ORTEGA HH: Expression of cytoskeletal proteins in the follicular wall of induced ovarian cysts. Cells Tissues Organs 178: 117-125, $2004 \mathrm{~b}$.

SCHULSTER A, FAROOKHI R, BRAWER JR: Polycystic ovarian condition in estradiol valerate-treated rats: spontaneous changes in characteristic endocrine features. Biol Reprod 31: 587-593, 1984.

SILVIA WJ, HATLER TB, NUGENT AM, LARANJA DA FONSECA LF: Ovarian follicular cysts in dairy cows: an abnormality in folliculogenesis. Domest Anim Endocrin 23: 167-177, 2002. 
SILVIA WJ, MCGINNIS AS, HATLER TB: A comparison of adrenal gland function in lactating dairy cows with or without ovarian follicular cysts. Reprod Biol 5: 19-29, 2005.

SINGH KB: Induction of polycystic ovarian disease in rats by continuous light. Am J Obstet Gynecol 104: 1079-1083, 1969.

SPINEDI E, GIACOMINI M, JACQUIER MC, GAILLARD RC: Changes in the hypothalamo-corticotrope axis after bilateral adrenalectomy: evidence for a median eminence site of glucocorticoid action. Neuroendocrinology $\mathbf{5 3}$ : 160-170, 1991.

STENER-VICTORIN E, PLOJ K, LARSSON BM, HOLMÄNG A: Rats with steroid-induced polycystic ovaries develop hypertension and increased sympathetic nervous system activity. Reprod Biol Endocrinol 3: 44, 2005.

THOMAS G, FRENOY N, LEGRAIN S, SEBAG-LANOE R, BAULIEU EE, DEBUIRE B: Serum dehydroepiandrosterone sulfate levels as an individual marker. J Clin Endocrinol Metab 79: 1273-1276, 1994.

TSILCHOROZIDOU T, HONOUR JW, CONWAY GS: Altered cortisol metabolism in polycystic ovary syndrome: insulin enhances 5alpha-reduction but not the elevated adrenal steroid production rates. $J$ Clin Endocrinol Metab 88: 5907-5913, 2003.

VAN DEN HURK R, DIJKSTRA G, VAN MIL FN, HULSHOF SC, VAN DEN INGH SGAMTH: Distribution of the intermediate filament proteins vimentin, keratin, and desmin in the bovine ovary. Mol Reprod Dev 41: 459467, 1995.

VERKERK GA, MACMILLAN KL, MCLEAY LM: Adrenal cortex response to adrenocorticotropic hormone in dairy cattle. Domest Anim Endocrinol 11: 115-123, 1994.

XITA N, GEORGIOU I, TSATSOULIS A: The genetic basis of polycystic ovary syndrome. Eur J Endocrinol 147: 717-725, 2002.

YILDIZ BO, WOODS KS, STANCZYK F, BARTOLUCCI A, AZZIZ R. Stability of adrenocortical steroidogenesis over time in healthy women and women with polycystic ovary syndrome. J Clin Endocrinol Metab 89: 5558$5562,2004$.

\section{Reprint requests}

Hugo H. Ortega, Department of Anatomy and Histology, Faculty of Veterinary Sciences, National University of Litoral, R.P. Kreder 2805, (3080) Esperanza, Santa Fe, Argentina. Fax: +54-3496-426304. E-mail: hhortega@fcv.unl.edu.ar 